\title{
Chapter 10 \\ Sweeping the Streets, Cleaning Morals: \\ Chinese Sex Workers in Paris Claiming \\ Their Belonging to the Cosmopolitan City
}

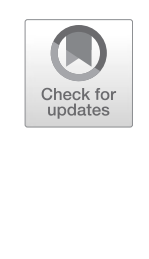

\author{
Hélène Le Bail and Marylène Lieber
}

\subsection{Introduction}

Since 2016 hundreds of Chinese migrants selling sexual services in Paris have been the target of systematic control operations by the police, whose clear objective is to "sweep" prostitution out of migrant neighborhoods in Paris's 13th and 19th arrondissements. In reaction to these measures, a group of Chinese sex workers organized the collective "The Steel Roses" [Les Roses d'Acier] and petitioned the local government to focus on preventing violence against sex workers rather than fighting sex workers. The Steel Roses is an attempt to embody political agency by demanding the local government for sex workers to be included as part of "local diversity" and to be considered legitimate users of the city. One of the collective's key initiatives was to sweep the streets in order to engage in dialogue with neighbors. As the collective put it in a public speech: "By sweeping the ground here, we take our responsibility. We live here. We laugh here, we cry here, we work here. We want to show that we are part of this neighborhood." In the context of local gentrification, where diversity is presented as an important characteristic of multicultural neighborhoods, this mobilization by migrant sex workers underlines the ongoing controversy around the definition of "diversity" as well as the controversy over who can legitimately claim to be part of the urban symbolic order.

\footnotetext{
H. Le Bail (ه)

CNRS CERI, Sciences Po, IC Migrations, Paris, France

e-mail: helene.lebail@sciencespo.fr

M. Lieber

Institute for gender studies, Department of Sociology, University of Geneva,

Geneva, Switzerland
} 
"Diversity" is a key word in the local political arena of contemporary France. It is used to promote a new image for districts and cities characterized by the presence of many migrants and their descendants. Discourses on urban diversity can be framed within academic debates on the "cosmopolitan city," in which cosmopolitanism is not understood as an individual way of life or philosophy (i.e., being a global citizen) but as an (collective) attitude, a form of openness to differences and diversity (Binnie et al. 2006), a tendency to value and promote diversity. Taking the case of Manchester city center, Young et al. (2006) describe how urban regeneration policies (often linked to gentrification processes) are based on cosmopolitan discourses, which in turn produce definitions of what is acceptable and not acceptable in terms of difference. They underline how narratives contribute to the framing of acceptable diversity: "The questions of what is 'acceptable' difference, who decides this and what impacts this has on diversity in cities highlight the inherently political nature of so-called cosmopolitan strategies" (Young et al. 2006, 1689). The controversy launched by the Chinese sex workers in some districts of Paris is another case study of how political power relations contribute to the definition of diversity and who belongs to a city defined in terms of cosmopolitanism.

Based on interviews with different actors (Chinese migrant women, elected representatives, NGOs and other supporters), the analysis of local debates (observation of local committees, minutes of city council meetings), and data on violence suffered by Chinese sex workers in Paris, this article questions the contingent place of migrant sex workers in official cosmopolitan narratives and documents their quest for recognition and belonging. A paradoxical definition of gender violence contributes to deny Chinese sex workers the right to be political agents and to be considered legitimate users of the city. We discuss the (hardly visible) contribution of migrant women in the discourse of cosmopolitan policies through the contested definitions of diversity, on the one hand, and of gender violence, safety and autonomy, on the other hand. In the context of "soft" gentrification, where various policies contribute to the eviction of "undesirable" populations or the suppression of "unacceptable" differences (not directly, but by encouraging the lifestyles of the privileged categories of population; see Young et al. 2006; Clerval and Fleury 2009), we argue that the hegemonic definition of gender violence contributes to the silencing and exclusion of migrant women sex workers. While the right to protection from gendered violence allows new claims and regulations protecting (white) women in public places and contributes to the process of gentrification targeting racialized masculinities (Lieber 2018), this same right is also mobilized to construct sex workers as heteronomous victims with no agency or as criminals, thus denying them the same protection from violence in public spaces and excluding them from equal participation in the constitution of cosmopolitan areas. In this article, we study how the double circumstances of a denied claim for local participation and a new abolitionist approach tend to further exclude sex workers from the cosmopolitan narratives on local diversity and the implementation of inclusive policies. 


\subsection{The Context: Chinese Prostitution in Gentrifying Districts of Paris}

In the early 2000s, a few Chinese migrant women started to sell sexual services around the red-light district of Paris, near Rue Saint-Denis. While some of them still work in this area along with "traditional" French sex workers and other migrant women, other spots of street work have appeared in districts of Paris not known for prostitution, such as Belleville and Triangle de Choisy.

Belleville has a long history of mixed populations. During the last century it was a gathering and settling place for many new immigrants. The Armenian, Greek, and Polish Jewish communities which developed there before the Second World War were largely replaced after the war, and running alongside the decolonization process, by Sephardic Jews from Tunisia (Simon and Tapia 1998) and Algerian migrant workers who found cheap hostels in the neighborhood. The area, which is close to one of the oldest places of residence for Chinese immigrants (Arts et Métiers) and remained relatively cheap until the beginning of the 2000s, was also a "way of entry" ("sas" in French) from the 1970s to the early 2000s for new Chinese migrants, especially ones from the Wenzhou community (Kloeckner 2017). Today the area is considered one of Paris's Chinatowns, with a Chinese population cohabiting with lively North African communities. Belleville is considered a cosmopolitan area of Paris. If a certain form of gentrification started decades ago with the arrival of artists who settled in Belleville because they could find cheap studios, the cosmopolitan and popular atmosphere of the district was accelerated in the early 2000s by the arrival of upper middle-class residents attracted by cheaper rents (Clerval 2017).

The case of the 13th district, and especially what is called the "Choisy Triangle" (Guillon and Taboada-Léonetti 1986), is quite different. Except for European immigrants during the first half of the twentieth century, the area has no history of hosting migrant communities. It was only when refugees from the former colonies of Indochina arrived in the 1970s and 1980s that a visible foreign community became established and that ethnic businesses developed. The Triangle de Choisy is now considered the main Asian district in Paris. It is the first area in which the council sought out dialogue with Asian residents and where Asian representatives were elected. The image of the district that is promoted is that of a middle-class, familyfriendly, safe area. The well-established Asian communities are largely gentrified. They defend this identity, which tends to exclude more popular or irregular use of public space.

In both of these districts, local councils are ruled by leftist parties (until recently, the Socialist Party) which value the cosmopolitan diversity of these areas. However, the current mayors of the 13th and 19th arrondissements espouse conservative security discourse, especially when it comes to public spaces and the presence of Chinese sex workers in their districts.

According to both official and NGO estimates, Chinese sex workers constitute one of the main groups of sex workers in Paris (the other main areas of origin are 
Eastern Europe, sub-Saharan Africa, and South America). ${ }^{1}$ They are visible and concentrated in areas where very few or no other sex workers go, such as the 13th and 19th arrondissements. Chinese migrant sex workers are marginalized both within the host society in general and within Chinese migrant communities. Like many other migrant sex workers, they tend to have an irregular legal status, precarious finances (having often arrived indebted) and unstable housing situations. They do not speak French or English, and their activity - sex work - is stigmatized. In addition, they are also often marginalized within existing Chinese networks that may facilitate access to housing and the job market. In fact, none of them are part of the main group of Chinese migrants in France, who come from the area of Wenzhou in Zhejiang province. They come from "new" places of emigration in China, places with no tradition of migration (Cattelain et al. 2005). Most of these women migrated outside of networks or just with the contact of a relative or some acquaintances. They engage in sex work because, as they put it, they cannot find a job within the "Chinese job market" in Paris or because the kind of jobs they can find as undocumented workers are very exploitative (Lévy and Lieber 2009; Lévy 2012; Le Bail 2017).

Besides their precarious and stigmatized situation as migrant sex workers, the ubiquity of violence in everyday life needs to be described to understand why these women mobilized themselves. Two different aspects of violence concurred in pushing their claims for recognition. First, like most migrant street sex workers, they are overexposed to all kinds of violence, and in particular physical and sexual violence, as reported in a 2010-11 survey by the NGO Doctors of the World. ${ }^{2}$ But like other sex workers, the violence they face does not only come from clients or from their activity (Mathieu 2002). The same survey also highlighted the fact that Chinese women were targeted by police operations under the law (between 2003 and 2016) criminalizing solicitation in public spaces. ${ }^{3}$ Paradoxically, they continued to be targeted by the police even after a new law passed in 2016 which decriminalized solicitation and criminalized clients.

\footnotetext{
${ }^{1}$ Most publications and actors in the field of sex work use the same sources: estimates by the OCRTEH which are based on police data on pimp affairs and arrests for soliciting. See also Mainsant 2014. According to the NGO Doctors of the World, who launched a reach-out program with translation services in 2004 targeting Chinese sex workers, the number of women they met through their actions in Paris increased from about 300-400 in 2005 to more than 600 in 2010 and then to more than 1000 in 2015 (Médecins du Monde, Activity Report of the Lotus Bus mission, 2005-2015, unpublished).

${ }^{2}$ Among the interviewees, $38 \%$ had been victims of rape since they started working in France, $23 \%$ victims of sequestration, and $17 \%$ of death threats. $86 \%$ answered that they had been victims of at least one form of violence. Médecins du Monde, "Travailleuses du sexe chinoises à Paris face aux violences," December 2012. The method was a mix of closed questions and semi-directive questions answered by 86 individuals.
}

${ }^{3}$ Médecins du Monde, “Travailleuses du sexe chinoises à Paris face aux violences," December 2012. 
In 2003 the "Loi de sécurité intérieure" extended the criminalization of solicitation to include passive solicitation (in other words, waiting for clients in a public space). However, the justice system tended to not support prosecutions of this extension and very few sex workers were prosecuted (Mainsant 2013). The offense of solicitation was mainly used by local authorities to regulate sex work in their localities, depending on the willingness of elected officials to respond to local neighborhood pressure. While police operations may have decreased in many places after the law changed in 2016, in the 13th and 19th arrondissements, where the number of Chinese sex workers increased in the 2010s, more police operations were launched on the demand of local authorities (Commission nationale Citoyens-JusticePolice 2013).

While many street sex workers hoped that the passage of the 2016 law would lead to loosened police control, other modes of control immediately replaced arrests for solicitation. In one area, the police began to carry out regular identity controls under the requisition by the public prosecutor of Paris. Even though such control operations are not supposed to target a specific population group, many Chinese sex workers have given evidence of being targeted. Some abusive practices by the police, such as verbal threats and depriving women of cash earnings, have also been reported. According to the general secretary of the syndicat de la magistrature [Magistrates Union], the collected statements could prove police harassment of Chinese sex workers in order to force them to move their places of work to another district. Another way to push sex workers out of an area is through operations targeting pimping. These operations target people renting rooms out for sex work, a practice forbidden in France. If these operations mainly target apartment owners and end in working apartments being shut down, in other instances police operations seem to target apartments where the Chinese women live, not work (as was the case in a 2013 operation). Among the tens of people arrested in that operation, almost all of them were rapidly released and not even considered as victims of pimping (Le Bail 2015). Such a police operation could be considered as a way to intimidate the Chinese women from working in a particular area.

Along with sex workers' unions and NGOs supporting Chinese sex workers considering these police operations as a form of violence, as well as a source of further stigmatization, precarity, and increased exposure to all forms of violence, migrant women started to voice their concerns in order to reverse the prevailing political logic of suppression and control (Le Bail 2015). This experience of violence alongside dialogue with various local activists allowed the Chinese migrant sex workers to have new perceptions and expectations. They began to defend their local belonging, asking for more security and for being considered as legitimate users of public spaces. 


\subsection{Cosmopolitanism from Below: A (Failed) Attempt to Redefine Local Diversity}

At the end of 2014 and the beginning of 2015, a group of Chinese sex workers created the collective Roses d'Acier (Roses d'Acier 2016; Le Bail 2015, 2017). One of its objectives was to find a way to communicate with residents to promote mutual understanding and reduce the complaints that are used by local authorities to instigate police operations. More or less at the same time, one of Belleville's district mayors (Belleville is under the governance of four different district councils) decided to increase police pressure in order to displace sex work from the area. At a public meeting in May 2015 focusing on prostitution the district mayor stated that "[p]rostitution jeopardizes the beautiful diversity of Belleville's neighborhood" (field notes). He considered this activity incompatible with Belleville as a district full of families. While implying that "beautiful diversity" (belle diversité) - both social diversity and the cultural heritage of different of waves of immigrants - was the area's identity, he also indicated that this diversity was a challenge - and so prostitution was a danger to the kind of balance local authorities wished to create. Indeed, as prostitution is not part of the history of this area, sex workers were not invited to the public meeting and were not considered potential participants or contributors to this "rich diversity" or as constituting a form of "acceptable" difference.

For local governments, the priority is not to protect sex workers as local residents but to eradicate prostitution from their neighborhood. The discourse on "diversity" in gentrifying areas often tends to put forward the interests of some residents (often the wealthiest and the newcomers) while sidelining others (young people, the homeless, sex workers) who are often categorized as disturbances (in the case of Belleville, see Clerval and Fleury 2009). The aforementioned public meeting was organized for the mayor to officially announce a special action to address the expectations of residents - terms that excluded resident Chinese sex workers. A few days later the police control operations around solicitation described above were launched. As a response, the Chinese sex workers' collective tried to start a dialogue with neighbors based on the idea that residents can influence local policy. At a meeting of over 60 sex workers, it was decided, with a certain humor, that since they were considered as undesirables who should be swept out of the area, they would, in response, literally sweep the pavements. This action also played with the meaning of the area's name: "What is Belleville [ND: "beautiful city" in French] the name of? They told us that because of us, Belleville is not beautiful anymore" (Roses d'Acier 2016). To re-embellish the area, they would sweep its streets:

We started in June, since at the end of May the police intensified control operations targeting the Chinese sex workers in Belleville area. We swept the streets again in July and September. ...

Sex work is a job that is very visible in the public space. It is not easy to be so visible and we know that some inhabitants are irritated. But we also have our families, and we do not want to annoy other families. Going once more in the streets and sweeping the ground is an opportunity to enter in dialogue with our neighbors. 
By sweeping the ground here, we take our responsibilities. We live here. We laugh here, we cry here, we work here, do the shopping here, and take the sun here. Some of us here are married, have children, form families. We want to show that we are part of this neighborhood.

What is Belleville (beautiful city) the name of? They told us that because of us, Belleville is not beautiful anymore, because we are ugly, we are dirty, and we are ignoble. But who are they to judge us? Are they more beautiful than us, cleaner than us, nobler than us? Solving social issues with violence is trying to humiliate us, insult us. To ignore our voice is to ignore our existence, to ignore our lives. (Roses d'Acier 2016, emphasis added)

By sweeping the streets, the collective tried to question the limits of abstract discourses on the "beauty" of the area - its "beautiful diversity." The Chinese migrant sex workers presented themselves as city users with families, as good mothers, not illegitimate users of the area. As we emphasized above, they claimed their right to be considered part of this diversity, part of the "neighborhood"; they claimed their right to the city and to local belonging in many speeches between 2014 and 2016. Since they were not invited to public meetings or local street events and were often refused appointments with local representatives, the collective created its own dialogue with other residents. During the sweeping operation (which was repeated three times in summer 2015), they asked supporters to distribute flyers in French and explain to passers-by their willingness to open up a dialogue. They also participated in a local street music festival in which anyone can perform without permission by singing Chinese songs and distributing flyers about the collective.

One year later, the decriminalization of solicitation had not stopped police harassment. The collective decided to organize a public meeting on prostitution in June 2016. With support from neighbors and other associations, other residents were invited to take part in this event in order to open a dialogue to find ways of coexistence. Central to the discussion was the issue of morality - i.e., the issue of "diversity of values" - and, most importantly, tranquility and security (with the usual assumption that sex workers attract noisy and violent people in their buildings and in the area in general). This question of security was also the core of the Chinese sex workers' arguments. They argued that measures to suppress prostitution create a vicious circle in which stigmatized sex workers tend to feel less legitimate in reporting violence to the police and that violent offenders may feel emboldened in their use of violence, resulting in greater insecurity and new demands from residents to repress sex work. This "vicious circle" (Roses d'Acier 2016) was meant to highlight the fact that Chinese sex workers were very much the victims rather than the cause of violence in public spaces. 


\title{
10.4 Disorder, Moral and Diversity: (Failed) Redefinition of Gender Violence
}

Two years later, in the Triangle de Choisy, also known for its Chinese-origin residents, Roses d'Acier also tried to reverse the logic of security measures after a video posted by the district mayor on his Facebook page described Chinese sex workers as a major menace to the quality of life and security of "families" and as a threat to public safety. Again, Chinese sex workers were constituted as illegitimate residents. The following is a transcription of the district mayor's speech, which was shot on a hidden camera on a street where Chinese women were working in the background:

\begin{abstract}
What you will see in this video is obvious: illegal street peddling, clandestine gaming tables, and prostitutes in front of a school. [...] One cannot bear this situation any longer. It is the everyday life of families living in the district that is severely deteriorated, in spite of all the initiatives we have taken to ameliorate people's wellbeing. The many investments done in the area are jeopardized by the mafia drift. And, when saying mafia drift, I still measure my words [...] I send a call to the Minister of Interior Affairs, Mr. Collomb. "Mr. Minister, like myself you have been a mayor before, like myself you know that the priority is to guarantee security and quality of life for residents, like myself, you understand how difficult a mission it is. I ask you to put all the necessary means to secure prevention, intelligence service and repression. (Fieldwork document, emphasis supplied)
\end{abstract}

The Chinese sex workers' collective organized a meeting after the video was released. With the help of a supporting NGO, Les Roses d'Acier wrote a letter that was sent to all the elected representatives of the district and other association actors. Expressing their desire to open a dialogue, they reminded the mayor that they also belonged to the area and should be considered as residents of "our district":

\begin{abstract}
Mayor, we are the sex workers of the 13th district of Paris. We write to you today in order to express our anger regarding the video you posted on your Facebook page on 11 July 2017 dealing with security and the need to repress street "mafia drift." We rather would like to open a well-reasoned dialogue with the city hall and residents in the aim of finding solutions for better security and wellbeing in our district. Until today, the video had gathered more than 4600 views, and was passed on by leparisien.fr on July 12th. It sparked many reactions and discussions and turned the Chinese sex workers, an already vulnerable group of population, into scapegoats. (Fieldwork document, emphasis supplied)
\end{abstract}

Among various arguments, they questioned the mayor's manner of framing the issue of insecurity: "While we are the first victims of insecurity in the 13th district, you point to us as the source of insecurity" (Ibid.).

Besides the fact that the sex workers are not recognized as legitimate residents to be considered under the rubric of "diversity," these different cases also underline the difficulty in being recognized as targets of violence. The presence of sex workers in urban and residential areas has always created moral anxiety over protecting "family" spaces and fears of neighborhood decline; these anxieties have led to "strategies of spatial containment" (Hubbard 2011). The political priority of urban tranquility, which insists on streets being cleared of any potential source of disorder, may partly explain why targeted local measures are not taken to address the risks of violence faced by sex workers. But another determinant factor is the revival of a 
prohibitionist, or neo-abolitionist, approach in the French political sphere which tends to exclude sex workers, as a sexual minority, from acceptable diversity. Paris is one city supporting such an approach (Mathieu 2014). The concrete impact of such an ideological approach is that the solution for sex workers is not to fight against the violence they are victims of in the public space but to help them "leave the street" - to push them to stop sex work and pressing for them to be invisible in the public space (Jakšić 2016). While the neo-abolitionists argue that they are trying to protect women from violence, the approach inevitably implies that sex workers cannot be part of the acceptable diversity of lifestyle, acceptable diversity of values. Although based on different ideas, tranquility policies and neo-abolitionists yield the same result: excluding sex workers from so-called "inclusive" narratives about migrant and socially mixed neighborhoods like the 13th and 19th arrondissements.

After the 2015 "sweeping operation," the Groupe Ecologie de Paris engaged in a dialogue and answered the request of the Chinese sex workers asking for more protection from the State. These representatives presented a resolution at four local councils (10,11, 19 and 20th districts of Paris) and a few weeks later, at the council of Paris (gathering the 20 districts), which sparked a large debate. Their request was for better prevention against violence suffered by sex workers rather than fighting against sex workers themselves. ${ }^{4}$

- We ask the Prefect to re-assign police forces to the fight against violence targeting sex workers, in particular to networks of human trafficking, instead of fighting against sex workers themselves (...)

- We propose the constitution of a citizen panel in order to work on solutions through the consultation of all the actors, including representatives of prostitutes themselves. ${ }^{5}$

The council members from the Socialist, Communist, and right-wing "Les Républicains" parties voted against re-assigning police operations from targeting sex workers to preventing violence against them on the grounds that doing so would lead to the "institutionalization of prostitution," which was defined as "one of the most violent expressions of patriarchy." The arguments related to tranquility and those supporting neo-abolitionism (which was then under discussion in the French Parliament) were presented as intimately linked to each other:

We are mobilized in the aim of putting an end to the prostitution stage. Our approach conciliates the willful fight against networks [the councilor implies that the arrests of sex workers would be done in the objective of fighting against exploitive criminal networks], $a$ supporting program to help victim women get access to their rights, to health prevention and to stop prostitution, and finally the possibility in the short term to free the public space. ${ }^{6}$ (Socialist councilor, emphasis supplied)

\footnotetext{
${ }^{4}$ Minutes of local councils: Municipality of the tenth arrondissement of Paris, 15 June 2015, 63; Municipality of the 20th arrondissement of Paris, 18 June 2015, 43.

5 "Conseil Municipal et départemental des lundi 29, mardi 30 juin, mercredi 1er et jeudi 2 juillet 2015," 23 September 2015, at www.paris.fr

6 "Conseil Municipal et départemental des 29-30 juin et 2 juillet 2015," 23 September 2015, 436.
} 
In this quote, sex workers are depicted as victims of trafficking whose rights as women are incumbent upon their stopping engaging as prostitutes, which in turn is considered a way to "free the public space." In this blurring of categories, victimhood and being a burden to the public space are connected. A large majority rejected the idea that sex workers should be protected, like other residents, by classic police operations. For prostitutes the only solution would be to stop working and "free up the public space." In other words, the legitimate violence to fight against is prostitution per se, pimping and trafficking, but not the other forms of violence that sex workers face. This case study of the ongoing controversy around the definition of gender violence and safety in the public space is a grounded example of how discourse on diversity is constructed and negotiated and how legitimate users of the city are defined along views of acceptable activities and morality.

\subsection{Conclusion}

While discourse on gender violence does not target the notion of diversity per se, the acceptability of sex work, like other forms of sexual minority practices and identities, is clearly one controversial aspect of diversity and a test of how tolerant and open to difference a city is (Hubbard 2000; Papayanis 2000). By not acknowledging the political agency of migrant sex workers and denying them a voice, local authorities reinforce a classist interpretation of what local diversity should be and deny migrant sex workers the right to participate in the everyday life of these areas. Analyzing this demand for local belonging by migrant sex workers and examining the contested definition of gender violence allow for a further development of the critique of the narrow use of cosmopolitanism by highlighting the definition of who can or should embody diversity in such narratives. This analysis shows that a radical distinction made in defining legitimate victims of gender violence leads to some women, in this case, migrant sex workers, as being perceived as problems for the public space. The blurring of victimhood and criminality contributes to the perception that sex workers are undesirable and unacceptable others, even in areas where narratives on diversity and cosmopolitanism are valued. All this underlines the normative and moral dimension of the notion of diversity, and by extension the classist definition of cosmopolitanism, in these areas of Paris.

Beyond questions about the city's physical attractiveness, gentrification, diversity and social mixing, the management of prostitution through a moral lens further excludes sex workers from the public space and from the local identity of areas with significant numbers of residents with a migrant background. The case of this collective action by Chinese migrant sex workers in Paris is a creative attempt to challenge an official discourse on diversity that appears to be exclusive; it also challenges discourses surrounding policies against gendered violence in public space end up excluding some women. The case study shows how the dichotomic approach of sex work - as violence per se and as a source of social disorder - allows political representatives to exclude sex workers from local processes of inclusion, depending on 
the context. As a source of social disorder, they are undesirable and excluded from discourses on diversity by not being considered as part of the neighborhood. As "victims of prostitution" (when prostitution is considered as a form of violence per se), they are excluded from measures to fight against gendered violence in public space, since the solution is to protect the sex workers by removing them from the public space. As such, multiple logics contribute to denying their attempt to speak, to be heard, and to use their political agency. Despite the failure of the initiatives of some Chinese migrant women in Paris, their claims highlight the constant redefinition of local urban identities. This example shows how even vulnerable city dwellers participate from below in constructing the city's cosmopolitan identity and image.

\section{References}

Binnie, J., Holloway, J., Millington, S., \& Young, C. (Eds). (2006). Cosmopolitan urbanism (259 p). London: Routledge.

Cattelain, C., Lieber, M., Saillard, C., \& Ngugen, S. (2005). Les Déclassés du Nord. Revue européenne des migrations internationals, 21(3). At http://journals.openedition.org/remi/2521

Clerval, A. (2017). Paris Sans Le Peuple: La Gentrification De La Capitale. Paris: La Découverte.

Clerval, A., \& Fleury, A. (2009). Politiques urbaines et gentrification, une analyse critique à partir du cas de Paris. L'Espace Politique, 8(2). At http://journals.openedition.org/espacepolitique/1314

Commission nationale Citoyens-Justice-Police. (2013, March). Un harcèlement institutionnalisé, Les prostituées chinoises et le délit de racolage public. At http://www.syndicat-magistrature. org/Un-harcelement-institutionnalise.html

Guillon, M., \& Tabaoda-Leonetti, I. (1986). Le triangle de Choisy: un quartier chinois à Paris. Paris: CIEMI, l'Harmattan.

Hubbard, P. (2000). Desire/disgust: Mapping the moral contours of heterosexuality. Progress in Human Geography, 24(2), 191-217.

Hubbard, P. (2011). Cities and sexualities. London: Routledge.

Jakšić, M. (2016). La traite des êtres humains en France. De la victime idéale à la victime coupable. Paris: CNRS Éditions.

Kloeckner, L. (2017). Belleville, quartier chinois à la croisée des flux migratoires. In T. Sanjuan (Ed.), Les chinatowns: trajectoires urbaines de l'identité chinoise à l'heure de la mondialisation (pp. 245-279). Paris: Prodig.

Le Bail, H. (2015). Mobilisation de femmes chinoises migrantes se prostituant à Paris. De l'invisibilité à l'action collective. Genre, sexualité \& société, 14. At http://gss.revues.org/3679

Le Bail, H. (2017, May 30). Les travailleuses du sexe chinoises entre repression et revendication. La vie des Idées.

Lévy, F. (2012). La Migration des Chinoises du Nord: une alternative genrée? Perspectives chinoises. At http://perspectiveschinoises.revues.org/6423

Lévy, F., \& Lieber, M. (2009). La sexualité comme ressource migratoire, Les Chinoises du Nord à Paris. Revue Française de Sociologie, 50(4), 719-746.

Lieber, M. (2018). 'From territories to city centers': The ambivalent management of women's safety and gentrification? French Politics, 16(1), 64-79.

Mainsant, G. (2013). Gérer les contradictions du droit 'par le bas'. Logiques de police en concurrence dans le contrôle de la prostitution de rue à Paris. Actes de la recherche en sciences sociales, 198, 23-34.

Mainsant, G. (2014). Comment la Mondaine construit-elle ses populations cibles? Le genre des pratiques policières et la gestion des illégalismes sexuels. Genèses, 4(97), 8-25. At https:// www.cairn.info/revue-geneses-2014-4-page-8.htm 
Mathieu, L. (2002). Quand 'la peur devient une existence': Sur la place de la violence dans le monde de la prostitution. L'Homme et la société, 143-144, 47-63.

Mathieu, L. (2014). Invisibiliser et éloigner: quelques tendances des politiques de la prostitution. Regards croisés sur l'économie, 15, 290-301.

Papayanis, M. (2000). Sex and the Revanchist City: Zoning out the pornography in New York. Environment and Planning D: Society and Space, 18(3), 341-353.

Roses d'Acier. (2016, March). What gives them the right to judge us? Open Democracy. At https:// www.opendemocracy.net/beyondslavery/sws/roses-dacier/what-gives-them-right-to-judge-us

Simon, P., \& Tapia, C. (1998). Le Belleville Des Juifs Tunisiens. Paris: Autrement.

Young, C., Diep, M., \& Drabble, S. (2006). Living with difference? The 'Cosmopolitan City' and urban reimaging in Manchester. UK Urban Studies, 43(10), 1687-1714.

Open Access This chapter is licensed under the terms of the Creative Commons Attribution 4.0 International License (http://creativecommons.org/licenses/by/4.0/), which permits use, sharing, adaptation, distribution and reproduction in any medium or format, as long as you give appropriate credit to the original author(s) and the source, provide a link to the Creative Commons license and indicate if changes were made.

The images or other third party material in this chapter are included in the chapter's Creative Commons license, unless indicated otherwise in a credit line to the material. If material is not included in the chapter's Creative Commons license and your intended use is not permitted by statutory regulation or exceeds the permitted use, you will need to obtain permission directly from the copyright holder. 